\title{
Phospholipid Reactivation of Plasmalogen Metabolism
}

JOHN S. ELLINGSON and WILLIAM E. M. LANDS, Department of Biological Chemistry, The University of Michigan, Ann Arbor, Michigan 48104

\section{ABSTRACT}

This report is concerned mainly with the properties of an enzyme from rat liver microsomes which hydrolyzes the alkenyl ether bond of 1-(1'-alk-1'-enyl)glycero-3-phosphoryl-choline (alkenylGPC hydrolase).

Destruction of the normal environment of the microsomes by treatment with phospholipases $\mathrm{A}$ or $\mathrm{C}$ caused inactivation of the alkenyl-GPC hydrolase, which was then partially reactivated by the addition of exogenous phospholipids. Both sphingomyelin and diacyl-GPC were efficient in restoring activity; diacyl-GPE was less effective; and monoacyl-GPC and monoacyl-GPE were ineffective. The presence of two long hydrocarbon chains in the lipid activator is apparently required for reactivation, suggesting that interaction of hydrophobic areas of the enzyme with the phospholipid is necessary for maximal activity. High concentrations of sucrose mimicked the effect of phospholipids, and because the sucrose and diacyl-GPC did not show an additive effect, they may reactivate the enzyme in a similar manner.

Disrupting the enzyme's environment by freezing and thawing the preparation also resulted in a loss of enzymatic activity, which was restored by added exogenous phospholipids.

The alkenyl-GPC hydrolase was inhibited by imidazole and some of its derivatives. Histidine and $\mathrm{N}$-acetyl histidine did not inhibit the enzyme, presumably due to the presence of a negative charge on the carboxyl group rather than the steric bulk of that group, since histidine methyl ester did inhibit the enzyme. Kinetic evidence showed imidazole to be a competitive inhibitor. The enzymatic activity of imidazole-treated microsomes also increased following addition of exogenous phospholipids. Imidazole inhibition differed from the phospholipase $\mathrm{A}$-inactivation in that it was partially reversed by $\mathrm{KCl}$, but not by sucrose. Imidazole did not inhibit other microsomal enzymes tested, indicating that it is not a general inhibitor of membrane-associated enzymes.

\section{INTRODUCTION}

ThE IDEA HAS ARISEN that some enzymes associated with membranes require phospholipids (1-9). The evidence for this is that removal of phospholipids from membranes by some process such as extraction with wet acetone or by treatment with a phospholipase resulted in inactivation of the enzyme. The activity could then be restored to the enzyme by adding exogenous phospholipid to the inactivated enzyme. Thus complexes of phospholipids and proteins occur and are probably very important in determining the properties of a membrane. Studies on the actual mode of interaction of the phospholipids with membrane-associated proteins have shown that both the polar and nonpolar moieties of the phospholipid can interact with proteins $(10,11)$.

Warner and Lands (12) have described an enzyme present in rat liver microsomes which hydrolyzes the alkenyl ether bond of 1-(1'alk-1'-enyl)-glycero-3-phosphorylcholine. This report presents evidence that this enzyme requires phospholipids. The enzyme is also inhibited by imidazole, and some properties of this inhibition are described.

\section{MATERIALS AND METHODS}

\section{Enzyme Assays}

The activity of 1-(1'-alk-1'-enyl)-glycero-3phosphorylcholine alkenyl ether hydrolase (alkenyl GPC-hydrolase) was measured by assaying aliquots from a $1 \mathrm{ml}$ incubation mixture containing $9.9 \mu$ moles of potassium phosphate buffer, $\mathrm{pH} 7.1,1.2 \mu$ moles of the substrate, 1(1'-alk-1'-enyl) - glycero-3-phosphorylcholine, and about $2 \mathrm{mg}$ of microsomal protein. The reaction was started by adding $0.3 \mathrm{ml}$ of a $4 \times 10^{-3} \mathrm{M}$ solution of alkenyl-GPC dissolved in either distilled water or in $0.033 \mathrm{M}$ potassium phosphate buffer, $\mathrm{pH}$ 7.1. The aliquots $(0.1 \mathrm{ml})$ were removed at timed intervals and added to a test tube containing $1 \mathrm{ml}$ of chloroform:methanol $(2: 1, v / v)$, and the tube was shaken slightly. Then $1 \mathrm{ml}$ of chloroform and $1 \mathrm{ml}$ of chloroform:methanol (2:1) were added successively with shaking. The resulting mixture was filtered through glass wool by passing it through a 9-in. Pasteur pipette containing a small wad of glass wool. The original tube was washed twice with $1 \mathrm{ml}$ portions of 
chloroform:methanol $(2: 1)$, each of which was transferred to the second tube by passing it through the Pasteur pipette. The resulting mixture was evaporated at $50 \mathrm{C}$ on a rotary evaporator, and the residue was taken up in $0.5 \mathrm{ml}$ of methanol. The methanol solution was analyzed for the substrate, 1-(1'-alk-1'enyl)-glycero-3-phosphorylcholine, by a slight modification of the procedure of Gottfried and Rapport (13). Five-tenths $\mathrm{ml}$ of a $2.5 \times 10^{-4} \mathrm{~N}$ iodine solution in $3 \%$ potassium iodide was added, and the tube was shaken vigorously for about $10 \mathrm{sec}$ and allowed to stand for at least $10 \mathrm{~min}$. Then $4 \mathrm{ml}$ of $95 \%$ ethanol were added, the solution was mixed thoroughly, and the absorbance was measured at $355 \mathrm{~m} \mu$.

The activity of D-glucose-6-phosphate phosphohydrolase (ED 3.1.3.10) (glucose-6-phosphatase) was assayed by a modified procedure of Harper (14). The reaction was performed in an incubation mixture containing $16.7 \mathrm{mM}$ sodium citrate buffer, $\mathrm{pH} 6.5,32 \mathrm{~mm}$ glucose6-phosphate, $\mathrm{pH} 6.5$, and about $1 \mathrm{mg}$ microsomal protein in $1.5 \mathrm{ml}$. At timed intervals, $0.3 \mathrm{ml}$ aliquots were removed and analyzed for incrganic phosphate. The enzymic assay for acyl-CaA:1-acylglycero-3-phosphorylcholine acyltransferase (acyltransferase) was determined by the spectrophotometric assay described by Lands and Hart (15). The acylCoA hydrolase activity was measured by the same method used to measure the acyl-CoA $: 1$-acyl-GPC acyltransferase except that 40-60 $\mathrm{m} \mu$ moles of the acyl-CoA were used and 1acyl-GPC was omitted from the reaction mixture.

\section{Preparation of Enzymes}

Microsomes were prepared as described by Lands and Hart (15). A partially purified phospholipase A was prepared by dissolving $60 \mathrm{mg}$ of Crotalus adamenteus snake venom (Ross Allen's Reptile Institute, Silver Springs, Florida) in $1 \mathrm{ml}$ of $0.05 \mathrm{M}$ Tris-chloride buffer, pH 7.6 and put on a Sephadex G-100 column $(2.4 \times 36 \mathrm{~cm})$. The phospholipase $A$ was eluted with the same buffer. One-milliliter fractions were collected, and the active fractions were pooled.

\section{Preparation of Phospholipids}

The phospholipids were prepared by silicic acid chromatography as described previously (16-18). Sphingomyelin was prepared by dissolving a crude sphingomyelin fraction in a small volume of methanol and then treating it with $1 \%$ mercuric chloride in $90 \%$ aqueous acetic acid to hydrolyze alkenyl ethers present. Then $2 \mathrm{~N}$ methanolic sodium hydroxide was added to adjust the $\mathrm{pH}$ to about 9 to hydrolyze any esters present. After the saponification had proceeded 30 minutes at room temperature, the reaction mixture was neutralized by adding ethyl formate, and enough $\mathrm{CHCl}_{3}$ was added to make the chloroform: methanol ratio 2:1. The chloroform layer was washed twice with 0.1 volume of water and then evaporated. The residue was washed 4 times with diethyl ether, and the ether-insoluble sphingomyelin was then purified by silicic acid column chromatography using chloroformmethanol solvent mixtures. The 1-(1'-alk-1'enyl)-glycero-3-phosphorylcholine was prepared as described before (16) except that twice as much methanolic sodium hydroxide was added, the saponification procedure was allowed to proceed for $30 \mathrm{~min}$ at room temperature, and ethyl formate was added to neutralize the saponification mixture.

The sonicated lipids for reactivation studies were made by adding $150 \mu$ moles of a pure phospholipid to a hand homogenizer (Dounce ball-type, Blaessig Glass Co.), and evaporating the solvent. Then $6 \mathrm{ml}$ of cold $0.25 \mathrm{M}$ sucrose, $0.001 \mathrm{M}$ EDTA were added to the homogenizer, and the mixture was homogenized to produce a milky emulsion of the phospholipid. This emulsion was sonicated for 15 min at full power on a Branson model 75SL sonifier using an ice-salt-water bath to maintain the temperature at less than $15 \mathrm{C}$. The sonified mixture was adjusted to a final volume of $15 \mathrm{ml}$ with the sucrose-EDTA. The diacylGPC preparations were centrifuged at 100,000 $\times g$ for $1 \mathrm{hr}$, and the opalescent solution beneath the floating lipid layer was collected and used.

\section{Treatment of Microsomes with Phospholipases}

Microsomes were adjusted to a concentration of $10-15 \mathrm{mg}$ protein per $\mathrm{ml}$ with $0.25 \mathrm{M}$ sucrose, 0.001 M EDTA. This suspension was sonicated for $4 \mathrm{~min}$ on a Branson model 75SL sonifier at a power of 6 amperes. An icesalt-water bath was used to keep the temperature between $\mathrm{OC}$ and $10 \mathrm{C}$. The sonicated microsomes were diluted with an equal volume of $0.05 \mathrm{M}$ Tris-chloride buffer, $\mathrm{pH} 7.4$. To the diluted microsomes $60 \mu \mathrm{l}$ of the partially purified phospholipase A ( $2 \mathrm{mg}$ protein $/ \mathrm{ml})$ and $30 \mu \mathrm{l}$ of $0.1 \mathrm{M}$ calcium chloride were added for each milliliter of the diluted microsomes, and the solution was rapidly mixed. For phospholipase $\mathrm{C}$ treatment, $3 \mathrm{mg}$ of fatty acid-poor bovine serum albumin, $60 \mu \mathrm{l}$ of a solution of Clostridium perfringens phospholipase C ( 120 $\mathrm{mg} / \mathrm{ml}$ ), and $30 \mu \mathrm{l}$ of $0.1 \mathrm{M}$ calcium chloride were added for every $\mathrm{ml}$ of diluted micro- 
somes. When samples were to be used for alkenyl hydrolase assay, $0.4 \mathrm{ml}$ aliquots were removed and added to a test tube containing $0.05 \mathrm{ml}$ of $0.5 \mathrm{M}$ EDTA, pH 7 which stops the phospholipase reaction by complexing the calcium ions required for phospholipase activity.

Phospholipids were extracted from the treated microsomes by adding $0.1 \mathrm{ml}$ aliquots of the microsome-phospholipase mixture to $1 \mathrm{ml}$ of chloroform:methanol $(2: 1)$. This mixture was evaporated under nitrogen, and another $\mathrm{ml}$ of the chloroform : methanol was added and evaporated. The residue was taken up in $0.1 \mathrm{ml}$ of the chloroform : methanol $(2: 1)$.

For thin-layer chromatography, $80 \mu \mathrm{l}$ of the solution of the phospholipids extracted from the microsomes was spotted on a thin-layer plate spread with Absorbosil No. 2, which had just been heated at $80 \mathrm{C}-100 \mathrm{C}$ for $15 \mathrm{~min}$ and cooled to room temperature. Overheating of the plate was avoided because it lowered the $R_{f}$ of the diacyl-GPE. The separation was accomplished by developing the plate successively in the following three solvent systems:

(1) chloroform: methanol: ethanol : water: acetic acid $(100: 16: 20: 4: 1)$

(2) methanol: $95 \%$ ethanol $(1: 3)$

(3) $95 \%$ ethanol : ether : methanol : water $(100: 25: 25: 2)$

The first solvent was allowed to travel a distance of about $15 \mathrm{~cm}$ on the plate. The plate was allowed to dry for about $15 \mathrm{~min}$ between the transfers from one solvent to the next. The last two solvents were allowed to travel up to the diacyl-GPE spot which had been detected by rhodamine $G$. The detection was accomplished by spraying one side of the plate where a standard diacyl-GPE had been put on the plate. The three solvent systems resulted in the separation of the mono- and diacyl derivatives of GPC and GPE from each other. Each compound was identified by comparing its $\mathbf{R}_{\mathrm{f}}$ to that of a standard.

After the final solvents had evaporated from the plate, it was sprayed with the molybdate spray described below to detect the phosphate positive areas of the plate. The areas containing the phospholipids were scraped into tubes, and $0.6 \mathrm{ml}$ of $70 \%$ perchloric acid was added. This mixture was heated at $185 \mathrm{Cf}$ or $2 \mathrm{hr}$ and then cooled to room temperature. Phosphate was measured by the procedure of Bartlett (19).

The molybdate spray was made from 2 solutions. The first solution was prepared by adding $40.11 \mathrm{~g} \mathrm{MoO}_{3}$ to 1 liter of concentrated sulfuric acid and heating gently until the $\mathrm{MoO}_{3}$ dissolved. The second one was made

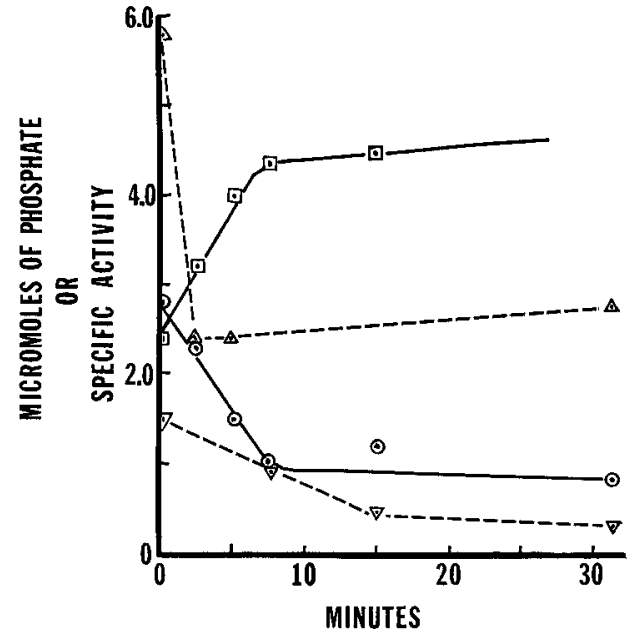

FIG. 1. Inactivation by phospholipase A. Treatment of the microsomes with phospholipase $A$, the removal of aliquots for alkenyl-GPC hydrolase assay and for phospholipid analysis, the analysis of the phospholipids, and the assay for the alkenyl GPC hydrolase under Methods. The figure shows the amount of diacyl-GPC $(\mathrm{O}-\mathrm{O})$, monoacylGPC ( $\square-\square)$, and diacyl-GPE $(\nabla---\nabla)$ present after various amounts of time of phospholipase A treatment of microsomes. The specific activity (in $\mathrm{m} \mu \mathrm{moles} / \mathrm{min} / \mathrm{mg}$ protein) of the alkenyl-GPC hydrolase $(\triangle-\triangle \triangle)$ is also shown as a function of the time of phospholipase $A$ treatment.

by dissolving $1.78 \mathrm{~g}$ powdered molybdenum in $500 \mathrm{ml}$ of the first solution and heating gently for $15 \mathrm{~min}$. One $\mathrm{ml}$ of each solution was added to $3 \mathrm{ml}$ of water to make the spray, which detects phospholipids by producing a blue color.

\section{Chemicals}

Imidazole was purchased from Eastman Organic Chemicals, 1-methylimidazole from the Aldrich Chemical Co., and the other derivatives of imidazole from Sigma. These compounds were neutralized before use. Urea was obtained from Baker and Adamson, and the alkylated ureas were supplied by George Zografi, Department of Pharmacy, University of Michigan. Glucose-6-phosphate was purchased from Calbiochem.

\section{RESULTS}

\section{The Effect of Phospholipase A}

When sonicated microsomes were treated with the partially purified phospholipase $A$, the enzymatic activity of the alkenyl-GPC hydrolase was reduced by $50-70 \%$ in $20 \mathrm{~min}$. To show that the phospholipids in the microsomal mem- 
TABLE I

Effect of Products of Phospholipase A Reaction on Sonicated Microsomes

\begin{tabular}{|c|c|}
\hline Additions & $\begin{array}{c}\text { Rate } \\
(\mathrm{m} \mu \text { moles } / 10 \mathrm{~min})\end{array}$ \\
\hline $\begin{array}{l}\text { None } \\
0.33 \mu \text { mole each of } 16: 0,18: 0 \\
\text { and } 18: 1 \text { fatty acids }\end{array}$ & $\begin{array}{r}375 \\
375 \\
\end{array}$ \\
\hline $\begin{array}{l}\text { Santoquin } \\
\text { Santoquin }+0.3 \mu \text { mole } 18: 3,0.4 \\
\quad \mu \text { mole } 18: 1, \text { and } 0.4 \mu \text { mole } 18: 2 \\
\text { fatty acids }\end{array}$ & 275 \\
\hline $\begin{array}{l}\text { None } \\
0.21 \mu \text { mole monoacyl-GPC } \\
0.42 \mu \text { mole monoacyl-GPC }\end{array}$ & $\begin{array}{l}350 \\
360 \\
375 \\
\end{array}$ \\
\hline $\begin{array}{l}\text { None } \\
0.42 \mu \text { mole monoacyl-GPC }\end{array}$ & $\begin{array}{l}325 \\
313\end{array}$ \\
\hline
\end{tabular}

The alkenyl-GPC hydrolase activity was determined as described under Methods with $3.9 \mathrm{mg}$ of protein in a 1.1 $\mathrm{ml}$ incubation mixture. The incubation mixtures had the amounts of fatty acids or monoacyl-GPC indicated. The enzyme and lipid were allowed to incubate for $5 \mathrm{~min}$ before the assay was initiated by addition of the substrate.

Fatty acids were added:

1) from a solution containing $11 \mu$ moles each of 16:0, $18: 0$, and $18: 1$ fatty acids and $27 \mu$ liters of absolute ethanol per $\mathrm{ml}$ of $0.05 \mathrm{M}$ Tris-chloride buffer, $\mathrm{pH} 7.4$. The control had an equal amount of Tris-chloride-absolute ethanol solution containing no fatty acids.

2) from a solution containing $40 \mu$ moles of each 18:1, and 18:2 fatty acids and $30 \mu$ moles of 18:3 fatty acid in $3 \mathrm{ml}$ of $0.05 \mathrm{M}$ Tris-chloride buffer, $\mathrm{pH}$ 7.4. A small amount of the antioxidant Santoquin (1,2-dihydro-6-ethoxy2,2,4-trimethyl quinoline) was present in the polyunsaturated fatty acids, so a solution of Tris and Santoquin containing no fatty acids was added to the control.

Monoacyl-GPC was added:

1) by adding a known amount from a chloroform: methanol (1:1) solution to a test tube and evaporating the solvent under nitrogen. The lipid was dissolved in the incubation medium to which the enzyme and substrate had not yet been added.

2) by adding an aliquot from an aqueous solution containing $4.2 \mu$ moles monoacyl-GPC per $\mathrm{ml}$ to the incubation medium (lowest section of the table).

branes were being hydrolyzed by phospholipase A, the lipids were extracted from a microsomephospholipase incubation mixture at timed intervals and analyzed. The results of such an experiment are shown in Fig. 1. The rate of disappearance of diacyl-GPC was equal to the rate of

TABLE II

Reactivation of Phospholipase A-Treated Enzyme with Diacyl-GPC

\begin{tabular}{lc}
\multicolumn{1}{c}{ Treatment } & $\begin{array}{c}\text { Rate } \\
(\mathrm{m} \mu \text { moles } / 10 \mathrm{~min})\end{array}$ \\
\hline Sonicated & 375 \\
PLA-treated & 125 \\
PLA $+0.2 \mu$ mole diacyl-GPC & 138 \\
PLA $+0.8 \mu$ mole diacyl-GPC & 263 \\
PLA $+2.0 \mu$ moles diacyl-GPC & 338
\end{tabular}

The microsomes were sonicated and treated with phospholipase $A$ as described under Methods. The alkenylGPC hydrolase was assayed as stated under Methods using $3 \mathrm{mg}$ protein. Sonicated diacyl-GPC was added in the amounts indicated.

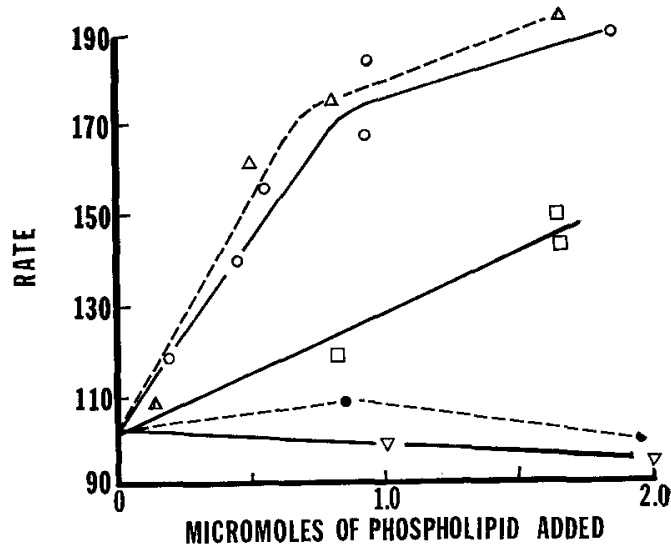

FIG. 2. Reactivation of phospholipase-treated enzyme by phospholipids. The enzyme was sonicated and treated with phospholipase $\mathbf{A}$ for 30 minutes as described under Methods. The enzyme was assayed as described in Methods using $3 \mathrm{mg}$ protein. The figure shows the enzymatic rate (expressed as $\mathrm{m} \mu \mathrm{moles} / \mathrm{min} / \mathrm{mg}$ protein) of the phospholipase-treated enzyme in the presence of different amounts of sonicated diacyl-GPC $(\mathrm{O}-\mathrm{O})$, sphingomyelin $(\triangle--\triangle)$, diacyl-GPE $(\square-$ $\square)$, monacyl-GPC (•- $\bullet$ ), and monoacylGPE $(\nabla-\nabla)$.

appearance of monoacyl-GPC. The rate of gain on monoacyl-GPE (not shown in the figure) was found to be equal to the loss of diacylGPE. Thus the rate of loss of the substrates of the phospholipase A reaction was equal to the rate of gain of the products. The data presented in Table I show that the products of the phospholipase A reaction did not inhibit the alkenyl-GPC hydrolase activity. The phospholipase $\mathrm{A}$ incubation was done at $20 \mathrm{C}$ in the presence of $3 \times 10^{-3} \mathrm{M} \mathrm{CaCl}_{2}$, and the phospholipase A reaction was stopped with 0.06 $M$ EDTA, pH 7.0. Incubation at $20 \mathrm{C}$ for 30 min with either of these reagents did not cause inactivation of the alkenyl-GPC hydrolase.

Addition of diacyl-GPC prepared from egg yolks to the phospholipase-inactivated enzyme resulted in a reactivation of the enzyme, and the results presented in Table II show that the amount of reactivation was dependent on the amount of diacyl-GPC added. Other phospholipids were also tested for their ability to restore the inactivated enzyme. The results in Fig. 2 illustrate that both diacyl-GPC and sphingomyelin were good reactivators. DiacylGPE could reactivate, but was not nearly as efficient as diacyl-GPC or sphingomyelin. Monoacyl-GPC and monoacyl-GPE were totally ineffective as reactivators.

LIPIDS, Vol. 3, No. 2 


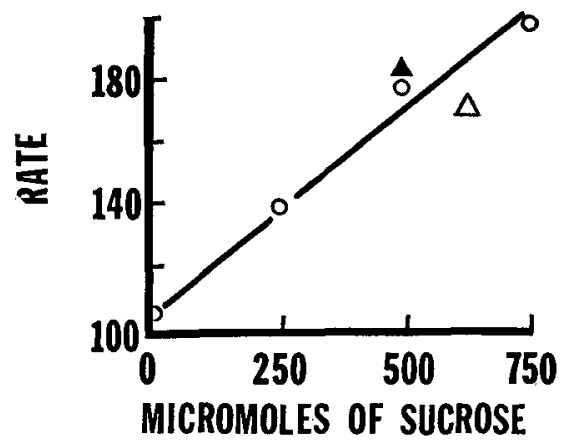

FIG. 3. Reactivation of phospholipase-treated by sucrose. The enzyme was sonicated and treated with phospholipase $\mathrm{A}$ for 30 minutes as described under Methods. The alkenyl-GPC hydrolase was assayed as described under Methods using $3 \mathrm{mg}$ of protein. The figure shows the rate (expressed as $\mathrm{m} \mu \mathrm{mole} / 10 \mathrm{~min}$ ) of the phospholipase-treated enzyme in the presence of different amounts of sucrose $(\mathrm{O}-\mathrm{O})$. The rate in the presence of both sucrose and sonicated diacyl-GPC is indicated by the symbols $\Delta$ and $\Delta$; the amount of sucrose present in the combination experiments is shown on the abscissa, and the amount of diacylGPC used was $0.93 \mu$ moles $(\mathbf{A})$ and $0.47 \mu$ moles $(\triangle)$.

The data in Fig. 3 indicate that high concentrations of sucrose, restored activity to the enzyme. Diacyl-GPC and sucrose did not have an additive effect. Two other polyols, glycerol and mannitol, were tested for the ability to reactivate the enzyme, and neither one restored activity.

\section{The Effect of Phospholipase C}

If intact phospholipids are really required by the enzyme, then the enzyme should be inactivated if they are degraded in a different

TABLE III

Effect of Freezing and Thawing

\begin{tabular}{lc}
\hline \multicolumn{1}{c}{ Conditions } & $\begin{array}{c}\text { Rate } \\
\text { (m } / \text { moles/10 } \min \text { ) }\end{array}$ \\
\hline None & 350 \\
$\quad$ Control & 363 \\
$\quad$ Control $+1.9 \mu$ moles diacyl-GPC & 257 \\
Frozen and thawed 10 times & 363 \\
Frozen and thawed 10 times +1.9 & \\
$\mu$ moles diacyl-GPC & \\
\hline
\end{tabular}

Microsomal preparations ( $9 \mathrm{mg}$ protein $/ \mathrm{ml}$ ) were made up in $0.2 \mathrm{M}$ sucrose, $0.001 \mathrm{M}$ EDTA. Each solution was frozen in a freezer maintained at $-20 \mathrm{C}$ and thawed in a cold water bath kept at $17 \mathrm{C}$ or less. Enzymatic activity was determined as described under Methods using $1.8 \mathrm{mg}$ microsomal protein and, where indicated, $1.9 \mu$ moles of sonicated diacyl-GPC.

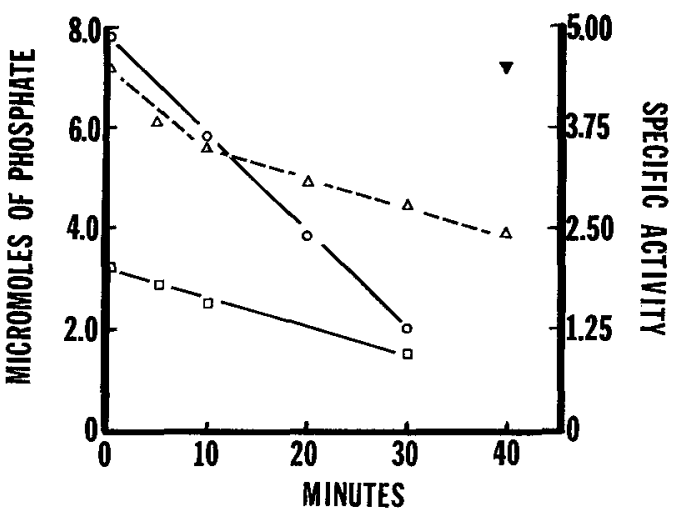

Fig. 4. Inactivation by phospholipase C. The sonication of microsomes, the treatment with phospholipase $\mathrm{C}$, and the analysis of phospholipids are described under Methods. The assay of alkenylGPC hydrolase was as described under Methods using $3 \mathrm{mg}$ of protein. Where indicated, $2 \mu$ moles of sonicated diacyl-GPC were added to the assay mixture of the enzyme treated with phospholipase $C$ for $40 \mathrm{~min}$.

The figure shows the amounts of diacyl-GPC $(\mathrm{O}-\mathrm{O})$, and diacyl-GPE ( $\square-\square$ - $\square$ ) present after different amounts of time of phospholipase treatment. It also shows the specific activity of the alkenyl-GPC hydrolase $(\triangle-\triangle \triangle$ ) as a function of the time of treatment with phospholipase C. The specific activity of the enzyme which had been treated with phospholipase for $40 \mathrm{~min}$ when assayed in the presence of $2 \mu$ moles of sonicated diacyl-GPC is indicated ( $\nabla$ ).

manner. This was tested by treating the microsomes with phospholipase C. Fig. 4 illustrates the phospholipase $\mathrm{C}$ degraded both diacyl-GPC and diacyl-GPE in the microsomal preparation. After 40 minutes, the alkylhydrolase was inactivated $50 \%$. When sonicated diacyl-GPC was added to the phospholipase $\mathrm{C}$-inactivated enzyme, activity was restored as indicated in Fig. 4.

\section{The Effect of Freezing and Thawing}

The alkenyl-GPC hydrolase was inactivated by freezing and thawing the microsomes several times. The enzyme activity was about $30-40 \%$ of the original value after being frozen and thawed 10 times. The enzyme was reactivated by diacyl-GPC, as shown in Table III. If diacyl-GPC was present during the freezing and thawing process, it failed to prevent the inactivation of the enzyme, and the enzyme no longer showed the ability to be reactivated by phosphatidyl choline. Also large particles settled out of the solution when microsomes were inactivated in the presence of diacyl-GPC. 
TABLE IV

Reversal of Imidazole Inhibition

\begin{tabular}{lc}
\hline \multicolumn{1}{c}{ Treatment } & $\begin{array}{c}\text { Specific activity } \\
(\mathrm{m} \mu \text { moles } / \mathrm{min} / \mathrm{mg} \\
\text { protein) }\end{array}$ \\
\hline $\mathrm{A}-$ None & 14 \\
$\mathrm{~B}-2.0 \mu$ moles Imidazole $/ \mathrm{ml}$ & 4 \\
$\mathrm{~A}-$ Centrifuged and resuspended & 18 \\
$\mathrm{~B}-$ Centrifuged and resuspended & 19 \\
\hline
\end{tabular}

A preparation of microsomes in $0.25 \mathrm{M}$ sucrose, 0.001 M EDTA was divided into two equal parts. One half was made up to $9 \mathrm{mg}$ protein per $\mathrm{ml}$ (total volume $=5 \mathrm{ml}$ ) with $0.25 \mathrm{M}$ sucrose, $0.001 \mathrm{M}$ EDTA, and the other half was made up to $9 \mathrm{mg}$ protein per microliter and $2 \mu$ moles of imidazole-chloride, $\mathrm{pH} 7.0$ per microliter. Each diluted preparation was centrifuged for 1 hour at $39,000 \mathrm{rpm}$ in a SW39 swinging bucket rotor. The resulting pellets were resuspended in $5 \mathrm{ml}$ of $0.25 \mathrm{M}$ sucrose, $0.001 \mathrm{M}$ EDTA. The resuspended pellets were then assayed for alkenylGPC hydrolase activity as described under Methods.

\section{The Inhibition of Imidazole}

Warner (20) found that imidazole inhibited the alkenyl-GPC hydrolase. As seen in Fig. 5, the enzyme was inactivated $50 \%$ when imidazole was present in concentrations of $1 \mu$ mole per milliliter of reaction mixture. The imidazole inhibition occurred immediately, for the same degree of inhibition occurred whether imidazole was added after the reaction had already begun or was preincubated with the enzyme for $30 \mathrm{~min}$ before the reaction was started. The reversibility of the imidazole inhibition of the hydrolase was demonstrated in two ways. Because the enzyme is particulate, it can be centrifuged at $100,000 \times g$ for one hour, and the resulting pellet can then be resuspended. When the enzyme was centrifuged from a medium containing $2 \mu$ moles of imidazole per milliliter and resuspended in a medium free of imidazole, the activity returned to control levels (Table IV). Table $\mathrm{V}$ reveals that the imidazole inhibition could be reversed by diluting the solution. When the enzyme was assayed with different amounts of substrate in

TABLE $\mathrm{V}$

Reversal of Imidazole Inhibition by Dilution

\begin{tabular}{lc}
\multicolumn{1}{c}{ Treatment } & $\begin{array}{c}\text { Rate } \\
\text { (m } \mu \text { moles } / 10 \mathrm{~min} \text { ) }\end{array}$ \\
\hline $\begin{array}{l}\text { None } \\
+2 \mu \text { moles Imidazole } / \mathrm{ml}\end{array}$ & 338 \\
$+0.4 \mu$ mole Imidazole $/ \mathrm{ml}$ & 75 \\
$\begin{array}{l}\text { Imidazole diluted from } 2.0 \mu \mathrm{m} / \mathrm{ml} \\
\text { to } 0.4 \mu \mathrm{m} / \mathrm{ml}\end{array}$ & 300 \\
\hline
\end{tabular}

A microsomal preparation was divided and diluted as described in the legend for Table IV. Then $0.2 \mathrm{ml}$ of each diluted enzyme was assayed as described in Methods. Imidazole hydrochloride, $\mathrm{pH} 7.0$, was added to the diluted microsomes containing no imidazole for the assays containing $2 \mu$ moles imidazole per microliter and $0.4 \mu$ mole imidazole per microliter.

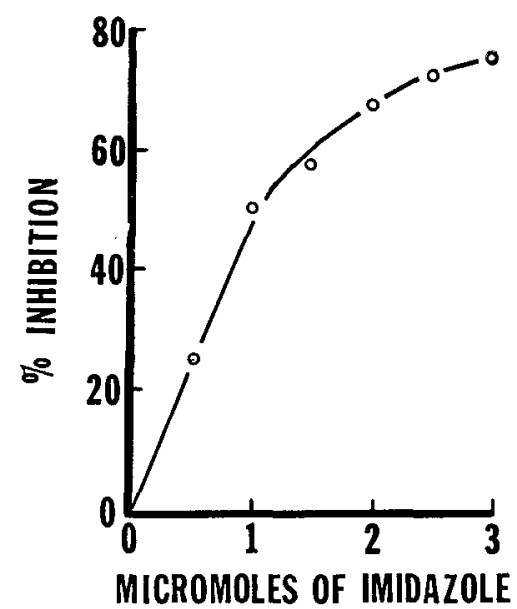

FIG. 5. Inhibition by imidazole. Enzymatic activity was determined as described under Methods using $1.8 \mathrm{mg}$ microsomal protein and a total volume of $1.0 \mathrm{ml}$. Imidazole was added in the amounts indicated before the reaction was started by adding substrate. The figure shows the percent inhibition of the enzymatic activity obtained with different amounts of imidazole.

the presence and absence of imidazole and the data were plotted according to the method of Lineweaver and Burk (21), a plot as shown in Fig. 6 was obtained. This graph indicates that imidazole is a competitive inhibitor.

Since Warner (20) had shown that histidine did not inhibit alkenyl-GPC hydrolase, the microsomes were treated with other derivatives of imidazole. As shown in Table VI the derivatives containing a negatively charged carboxyl group did not inhibit the enzyme, whereas all other compounds tested inhibited about $75 \%$ at a concentration of $0.003 \mathrm{M}$.

Urea is known to inhibit many enzymes, and as Table VII shows, it inhibits the alkenyl-

TABLE VI

Inhibition by Imidazole and Its Derivatives

\begin{tabular}{|c|c|c|c|}
\hline \multirow{2}{*}{$\begin{array}{l}\begin{array}{l}\text { Reagent added } \\
(3 \mu \text { moles } / \mathrm{ml})\end{array} \\
\text { None }\end{array}$} & \multicolumn{3}{|c|}{$\begin{array}{c}\text { Rate } \\
(\mathrm{m} \mu \mathrm{moles} / 10 \mathrm{~min})\end{array}$} \\
\hline & 213 & 250 & 263 \\
\hline Imidazole & 100 & 113 & \\
\hline N-Methylimidazole & 100 & & \\
\hline Histamine & & 113 & \\
\hline Histidine Methylester & & 150 & 75 \\
\hline N-Acetyl-histamine & 125 & 100 & 150 \\
\hline Histidine & 213 & 275 & \\
\hline N-Acetyl-histidine & & 263 & 263 \\
\hline
\end{tabular}

The enzyme was assayed as described under Methods using $1.8 \mathrm{mg}$ of protein. Each reagent was adjusted to pH 7.0 and added $5 \mathrm{~min}$ before the substrate solution was added to start the reaction.

LIPIDS, Vol. 3, No. 2 
TABLE VII

Inhibition by Urea

\begin{tabular}{lcc}
\hline Additions & $\begin{array}{c}\text { Rate } \\
(\mathrm{m} \mu \mathrm{moles} / 10 \mathrm{~min})\end{array}$ & $\begin{array}{c}\text { Percent } \\
\text { inactivation }\end{array}$ \\
\hline None & 473 & - \\
1.0 M Urea & 381 & 19 \\
3.0 M Urea & 184 & 61 \\
5.0 M Urea & 40 & 92
\end{tabular}

The enzyme was assayed as described under Methods using $1.3 \mathrm{mg}$ of protein and an incubation volume of 1.1 $\mathrm{ml}$. Where indicated, enough urea was added before the substrate to give the final concentration stated. The reagent and enzyme were allowed to incubate together for $5 \mathrm{~min}$ at room temperature before the substrate was added to start the reaction.

GPC hydrolase at high concentrations. The concentration of urea needed to achieve about $60 \%$ inhibition was $3.0 \mathrm{M}$. This is in contrast to imidazole which gave $75 \%$ inhibition at $0.003 \mathrm{M}$. The data in Table VIII also show that the addition of a hydrocarbon side chain to the urea molecule made it a more potent inhibitor of the enzyme. The difference between $1.0 \mathrm{M}$ urea and $0.1 \mathrm{M}$-butyl urea demonstrates that the ability of the alkylated ureas to inactivate the enzyme is greater with increasing length of the hydrocarbon chain.

\section{Relief of the Imidazole Inhibition}

Since the enzyme preparations inactivated by phospholipases and by freezing and thawing could be reactivated by phospholipids, the effect of these compounds on the imidazoleinactivated enzyme was studied. As Fig. 7 reveals, both sphingomyelin and diacyl-GPC reactivated the imidazole-inhibited enzyme. The amount of reactivation obtained being dependent on the amount of phospholipid added.

Because the phospholipase A-inactivated enzyme showed increased activity in the presence of sucrose, the effect of polyols on the imidazole inhibition was studied. The polyols sucrose, mannitol, and glycerol did not reactivate the imidazole-inhibited enzyme. However, the imidazole inhibition could be relieved by the addition of potassium chloride.

TABLE VIII

Inhibition by Alkylated Ureas

\begin{tabular}{lcc}
\hline \multicolumn{1}{c}{ Additions } & $\begin{array}{c}\text { Rate } \\
\text { (m } \mu \text { moles } / 10 ~ m i n)\end{array}$ & $\begin{array}{c}\text { Percent } \\
\text { inactivation }\end{array}$ \\
\hline None & 330 & - \\
1.0 M Urea & 289 & 12 \\
1.0 M Methyl urea & 289 & 12 \\
1.0 M Ethyl urea & 110 & 67 \\
0.5 M n-Butyl urea & 28 & 92 \\
0.1 M n-Butyl urea & 179 & 46 \\
\hline
\end{tabular}

Conditions were the same as described for Table VII except that $1.0 \mathrm{mg}$ protein was used in an incubation volume of $1.05 \mathrm{ml}$
TABLE IX

The Effect of Imidazole on Other Membrane-Associated Enzymes

\begin{tabular}{|c|c|c|}
\hline \multirow[b]{2}{*}{ Enzyme } & \multicolumn{2}{|c|}{$\begin{array}{c}\text { Specific activity } \\
(\mathrm{m} \mu \mathrm{moles} / \mathrm{min} / \mathrm{mg})\end{array}$} \\
\hline & $\begin{array}{l}\text { Without } \\
\text { Imidazole }\end{array}$ & $\begin{array}{c}3 \mathrm{mM} \\
\text { Imidazole }\end{array}$ \\
\hline Glucose-6-phosphatase & 51.5 & 61.5 \\
\hline Alkenyl-GPC hydrolase & 35.0 & 9.0 \\
\hline $\begin{array}{l}\text { Acyl CoA:1-Acyl-GPC-acyltransferase } \\
\text { with } 20: 4(n-6) \text { acyl-CoA }\end{array}$ & 35.0 & 29.0 \\
\hline Acyl-CoA hydrolase & & \\
\hline with $20: 4$ (n-6) acyl-CoA & 22.0 & 22.0 \\
\hline
\end{tabular}

The enzymes were assayed as described under Methods. When imidazole hydrochloride was included, it was added to a final concentration of $3.0 \mathrm{~mm}$, and it was added before the substrate was added to start the reaction.

Potassium chloride did not reactivate the alkenyl-GPC hydrolase activity in phospholipase A-treated microsomes.

Since phospholipids could bring about a reactivation of the imidazole-treated enzyme, and because phospholipids are known to reactivate certain other membrane-associated enzymes which have been inactivated, the effect of

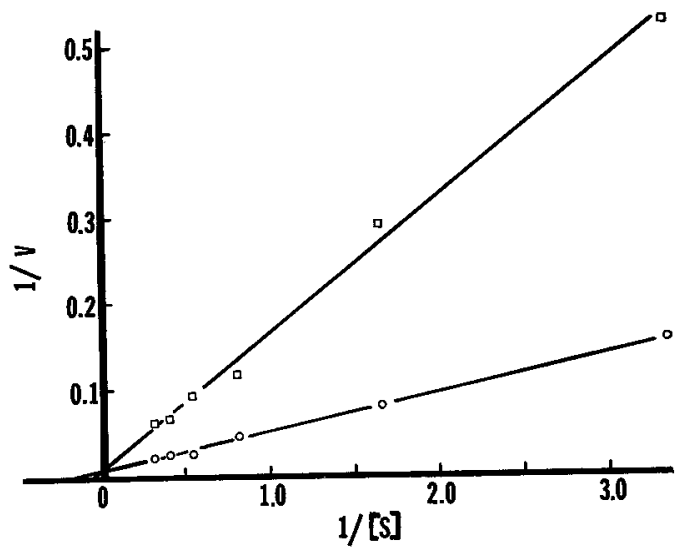

Fig. 6. The effect of substrate concentration on imidazole inhibition. The enzyme was assayed at $25 \mathrm{C}$ in the presence of $15 \mu$ moles of potassium phosphate buffer, pH 7.1, $1.8 \mathrm{mg}$ microsomal protein, and the amount of substrate indicated per milliliter of incubation mixture. Aliquots which contained about $0.1 \mu$ mole of substrate at zero time were removed and assayed as described under Methods. The reaction was initiated by adding the enzyme. The figure shows the enzyme rate obtained using different amounts of substrate. Where indicated two $\mu$ moles of imidazole hydrochloride, $\mathrm{pH} 7.0$, were added before the substrate. The figure shows the plots of reciprocal velocities ( $\mathrm{m} \mu \mathrm{moles} / \mathrm{min})^{-1}$ vs. reciprocal substrate concentrations ( $\mu$ moles $)^{-1}$ in the presence $(\square-\square)$ and absence $(\mathrm{O}-\mathrm{O})$ of imidazole. 


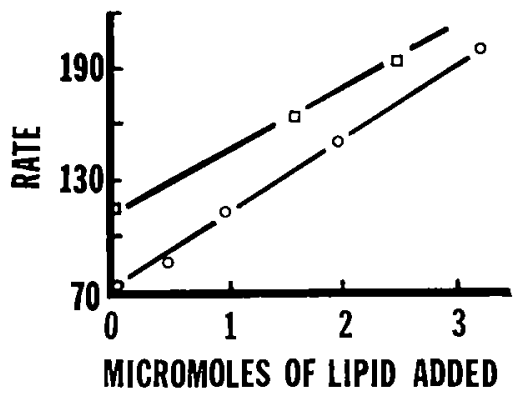

FIG. 7. Relief of imidazole inhibition by phospholipids. The enzyme was assayed as described under Methods using $1.8 \mathrm{mg}$ of protein in the presence of $2 \mu$ moles imidazole hydrochloride, pH 7.0. Sonicated phospholipids were added in the amounts indicated after the addition of the substrate solution. The figure shows the rate of the imidazole-treated microsomes in the presence of different amounts of diacyl-GPC (O-O) and sphingomyelin ( $\square-\square$ ).

imidazole on other membrane-associated enzymes was studied. Table IX shows that, of the microsomal enzymes tested, only alkenylGPC hydrolase was strongly inactivated by 3.0 mM imidazole.

\section{DISCUSSION}

Treatment of the sonicated microsomes with phospholipase A results in the loss of enzymatic activity. This suggests that the loss of activity is due to the destruction of the microsomal phospholipids. The phospholipids were actually degraded by the phospholipase $\mathrm{A}$ and the possibility that loss of enzymatic activity was due to the inhibition by the products of the phospholipase reaction was ruled out, as neither fatty acids nor 1-acyl-glycero-3-phosphorylcholine inhibited the enzyme. The fact that polyunsaturated fatty acids did not cause inhibition is especially important, since the fatty acids released from phosphatidyl choline and phosphatidyl ethanolamine by phospholipase $\mathrm{A}$ are released from the 2-position of the glycerol moiety (22-24), which contains mainly unsaturated fatty acids in naturally occurring phospholipids (25). I oss of activity was not attributable to any of the reagents used in the phospholipase treatment of the microsomes.

Addition of micellar phospholipids caused reactivation of the phospholipase-treated enzyme, the amount of reactivation being dependent on the amount of lipid added. Thus alkenyl-GPC hydrolase is similar to other membrane associated enzymes which have been treated with phospholipases and reactivated with phospholjpids. Reactivation by more than one phospholipid has been demonstrated for other enzymes such as glucose-6-phosphatase from rat liver microsomes (9) and ATPase from sarcosomes (5). Ganoza (9) found that phospholipase A-treated glucose-6-phosphatase was reactivated by both phosphatidyl choline and phosphatidyl ethanolamine, while phosphatidyl ethanolamine was not a very efficient reactivator of alkenyl-GPC hydrolase. Martonosi (5) found that both diacyl-GPC and monoacyl-GPC could reactivate the ATPase and the concomitant $\mathrm{Ca}^{+2}$ uptake of the sarcoplasmic reticulum after inactivation with phospholipase C. In fact, monoacyl-GPC was the more efficient reactivator. This is in direct contrast to inactivated alkenyl-GPC hydrolase which could not be reactivated with monoacylGPC. Thus microsomal enzymes display some selcctivity as to which phospholipids reactivate them, which makes it seem more plausible that phospholipids have specific functions in membranes and that reactivation is more than just an effect of surface-active compounds. This is especially apparent with lipid-deficient mitochondrial ATPase which is reactivated by both detergents and phospholipids, but only naturally occurring phospholipids restore the oligomycin sensitivity characteristic of the untreated enzyme (3). One membrane enzyme has been found which requires a specific phospholipid. This enzyme, $\beta$-hydroxybutyric dehydrogenase from mitochondria, shows an absolute requirement for phosphatidyl choline which has at least one unsaturated fatty acid component $(4,26)$.

Since phosphatidyl choline reactivates the alkenyl-GPC hydrolase but phosphatidyl ethanolamine reactivates less, some specificity for the polar group of the phospholipid molecule must exist. That sphingomyelin also reactivates the enzyme supports this conclusion, as it also has phosphorylcholine as a hydrophilic component. However, monoacyl-GPC does not effect reactivation, suggesting that there is also specificity for the apolar part of the phospholipid, two long hydrocarbon chains or else one chain linked to the 2-position apparently being required.

The importance of the hydrophobic areas for this enzyme's activity is also implicated by the fact that alkylated ureas are more potent inhibitors than urea, those with longer side chains being more potent inhibitors. The hydrocarbon side chains presumably interact with hydrophobic areas in the membrane, perhaps disrupting the interaction between the phospholipids and proteins.

The normal membrane environment can 
be considered as a phospholipid-protein arrangement, and destruction of the membrane phospholipids by phospholipase presumably destroys the native environment of the enzyme. The effect of adding phospholipid to the inactivated enzyme could be to reconstruct the natural membrane environment.

The phospholipase-treated enzyme was also reactivated by incubating it in high concentrations of sucrose. Because the addition of both phosphatidyl choline and sucrose did not have an additive effect in reactivating the enzyme, it does not seem likely that they acted differently. It is possible that both may cause a conformational change in the enzyme, converting it from an inactive form to an active form. Phospholipids could cause this by direct binding to the enzyme whereas sucrose might induce a similar change through an osmotic effect on the membrane, causing it to contract or become dehydrated. Microsomes are known to behave osmotically (27). If this is the cause of reactivation by sucrose, other polyols might mimic this effect. However, the two that were tested, glycerol and mannitol, did not elicit as large a reactivation as sucrose. Both are much smaller molecules than sucrose, and therefore might penetrate the membrane and not exert an osmotic effect. Sucrose could prove to be a useful tool in understanding how phospholipids reactivate the alkenyl-GPC hydrolase.

Treating sonicated microsomes with phospholipase $C$ results in the inactivation of the enzyme. The phospholipase $C$ reaction did not occur unless albumin was added, which could adsorb any monoacyl-GPC present. This lipid can be a potent inhibitor of phospholipase $\mathrm{C}$ (28). Microsomal phospholipids were shown to actually be degraded by this enzyme. The products of the reaction, diglyceride and phosphorylcholine and phosphorylethanolamine, differ from the products of the phospholipase $\mathrm{A}$ reaction, providing further evidence that the products of the phospholipase A reaction were not responsible for inactivation of the enzyme. The phospholipase $C$ treated alkenyl-GPC hydrolase was also reactivated by phospholipids. Phospholipase C treatment is a second way to hydrolyze membrane phospholipids and thereby inactivate the alkenylhydrolase, lending support to the idea that it requires intact diacyl phospholipids in its environment for maximal activity.

The process of freezing and thawing microsomes probably inactivates the alkenylGPC hydrolase by physical means. The en- zyme inactivated by this method was also reactivated with phospholipid. Glucose-6-phosphatase, which also requires phospholipids, is likewise inactivated by freezing and thawing (29). Lusena (30) has shown that the release of $\beta$-hydroxybutyric dehydrogenase from mitochondria by freezing and thawing is probably not due to the formation of ice per se, but exposure to transient high concentrations of sucrose and redilution being the main cause of damage. Electron microscopy revealed that under conditions where $\beta$-hydroxybutyric dehydrogenase was released, the mitochondria underwent drastic structural changes (31). Freezing and thawing microsomes probably produces similar alterations in their structure, destroying the normal membrane environment and disrupting interactions between the phospholipids and the proteins, thereby inactivating the alkenylGPC hydrolase. Adding phospholipid to frozen and thawed microsomes may restore enzyme-phospholipid interactions, and, consequently, enzymic activity.

Imidazole causes immediate inhibition of the alkenyl-GPC hydrolase, indicating that the site of interaction on the enzyme is readily accessible to the imidazole molecule. Urea also inhibits the enzyme, but there is about a 3000-fold difference in the concentrations of urea and imidazole required to achieve the same degree of inhibition. The alkenylGPC hydrolase was the only microsomal enzyme of those tested which was inhibited by imidazole, demonstrating it is a specific inhibitor of this enzyme and not a general inhibitor of microsomal enzymes.

Several derivatives of imidazole inhibited the enzyme at the same concentration as imidazole. The two derivatives which did not inhibit the enzyme, histidine and $\mathrm{N}$-acetylhistidine, had a negative carboxyl group present in the molecule. The steric bulk of the carboxyl group does not seem to be the responsible factor, since histidine methyl ester is as potent an inhibitor as imidazole. Thus, the negative charge must prevent histidine and $\mathrm{N}$-acetylhistidine from interacting with the enzyme in such a way as to cause inhibition.

Imidazole is known to bind divalent cations, so it might inhibit the enzyme by removing a tightly bound metal ion. However, the inhibition was reversible by dilution, indicating that imidazole does not remove a metal ion or any other cofactor.

Kinetic studies performed in the presence and absence of imidazole revealed that the inhibition of alkenyl-GPC hydrolase is competi- 


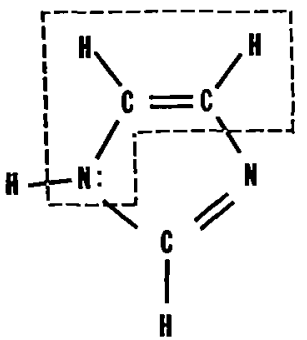

IMIDAZOLE

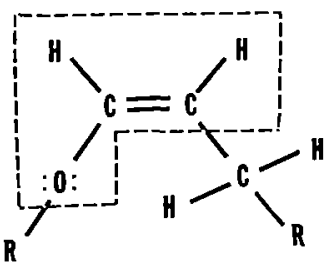

ALKENYL ETHER
FIG. 8. Structural formulas of imidazole and an alkenyl ether. The dotted line encloses the parts of each compound which are similar in structure.

tive. Reversibility of the inhibition is compatible with this result. Imidazole and the substrate might compete for the same site of the enzyme. Warner $(20)$ has pointed out that there are certain similarities between the structures of the normal substrate and imidazole or its derivatives namely, both have a cis double bond with an electron rich center in the vinyl position (Fig. 8). That imidazole inhibition is rather specific for the alkenyl-GPC hydrolase makes the idea that imidazole and the substrate compete for the same site more attractive.

Inhibition by imidazole could be partly reversed by phosphatidyl choline and sphingomyelin, the amount of reactivation being proportional to the amount of lipid added. Thus there are three ways of inactivating the enzyme where addition of phospholipids restores activity; hydrolysis of the lipoprotein phospholipid, freeze-thawing and imidazole addition. The imidazole-inhibited enzyme differs from the phospholipase A-inactivated one in that it is not reactivated by sucrose but is reactivated by potassium chloride. Exactly how the phospholipid reactivates the enzyme is not known for any of the three situations, but further study of the system may provide valuable insight into the role that phospholipids play in the micro-environment of cellular membranes.

\section{REFERENCES}

1. Lester, R. L., and S. Fleischer. Biochim. Biophys. Acta 47, 358-377 (1961).
2. Tzagaloff, A., and P. H. MacLennan, Biochim, Biophys. Acta 99, 476-485 (1965).

3. Kagawa, Y., and E. Racker, J. Biol. Chem. 241, 2461-2474 (1966).

4. Sekuza, I., P. Jurtshuk, Jr., and D. E. Green, J. Biol. Chem. 238, 3595-3605 (1963).

5. Martonosi, A., Biochem. Biophys. Res. Commun. 13,273 (1963).

6. Ohnishi, T., and H. Kawamura. J. Biochem. (Tokyo) 56,106 (1964).

7. Ohnishi, T., and H. Kawamura, J. Biochem. (Tokyo) 56,377 (1964).

8. Tanak, R., and L. G. Alood, Arch. Biochem. Biophys. 108, 47-52 (1964).

9. Ganoza, M. C., and W. I. Byrne, Federation Proc. $23,535(1963)$.

10. Green, D. E., and S. Fleischer, Biochim. Biophys. Acta 70, 554-582 (1963).

11. Green, D. E., and S. Fleischer, in R. M. C. Dawson and D. N. Rhodes (Editors), "Metabolism and Physiological Significance of Lipids," John Wiley and Sons, Itd., New York, 1964, p 581.

12. Warner. H. R., and W. E. M. Lands, J. Biol. Chem. 236, 2404-2409 (1961).

13. Gottfried, E. L., and M. M. Rapport, J. Biol. Chem. 237, 329-333 (1962).

14. Harper, E., in H. V. Bergmeyer (Editor), "Methods of Enzymatic Analysis," Academic Press, New York, 1965. p. 788 .

15. Lands. W. E. M., and P. Hart, J. Biol Chem. 240. 1905-1911 (1965).

16. Warner. H. R.. and W. F. M. Lands. J. Biol. Chem. $236,2404-2409$ (1961).

17. Lands, W. E. M., and I. Merk1. J. Biol. Chem. 238, 898-904 (1963).

18. Merkl, I., and W. E. M. I.ands, J. Biol. Chem. 238, 905-906 (1963)

19. Bartlett. G. R., J. Biol. Chem. 234, 466-468 (1959).

20. Warner, H. R.. "The Structure and Metabolism of Plasmalogen," Doctoral Thesis, The University of Michigan, Ann Arbor. Michigan, 1962; University Microfilms. Inc., 1962.

21. Lineweaver. H.. and D. Burk, J. Am. Chem. Soc $56,658-666$ (1934).

22. Hanahan, D. J., J. H. Brokerhoff and E. J. Barron. J. Biol. Chem. 235, 1917-1923 (1960).

23. de Haas. C. H., I. Mulder and L. L. M. van Deenen. Biochem. Biophys. Res. Commun. 3, 287 (1960).

24. Tattrie, N. H., J. Tipid Res. 1, 60-65 (1959).

25. Hanahan, D. J., "I.jpid Chemistry." John Wiley and Sons, Ltd., New York and London, 1960).

26. Sekuzu, I., P. Jurtshiek, Jr.. and D. E. Green. J. Biol. Chem. 238, 975-982 (1963).

27. Tedeschi, H., J. M. James and W. J. Antony, J. Cell. Biol. 18, 503 (1963).

28. Rodbell, M., J. Biol. Chem. 24I, 130-139 (1966).

29. de Duve, C., CIBA Foundation Colloquia on Endocrinology, 6, 22 (1953).

30. Lusena, C. V., Can. J. Biochem. 4.3, 1787 (1965).

31. Lusena, C. V., and C. M. S. Dass, Can. J. Biochem. 44, 775 (1966). 